R. Holderegger $\cdot$ S. Angelone $\cdot$ S. Brodbeck $\cdot$

D. Csencsics · F. Gugerli • S. E. Hoebee • R. Finkeldey

\title{
Application of genetic markers to the discrimination of European Black Poplar (Populus nigra) from American Black Poplar (P. deltoides) and Hybrid Poplars (P. x canadensis) in Switzerland
}

Received: 12 January 2005 / Accepted: 26 April 2005 / Published online: 12 August 2005

(C) Springer-Verlag 2005

\begin{abstract}
European Black Poplar (Populus nigra) is considered a rare and endangered tree species because of severe reduction of its natural riverine habitat and potential hybridisation with the related non-indigenous taxa $P$. deltoides and $P$. x canadensis. As it is difficult to distinguish these taxa solely based on their morphology, we applied a PCR-based assay with an easy-to-use and robust molecular marker set (cpDNA $\operatorname{trn} \mathrm{L}-\operatorname{trn} \mathrm{F} / \mathrm{R} s a \mathrm{I}$ RFLP, nDNA win3 and nDNA POPX/MspI RFLP) in order to identify pure P. nigra. Different plant tissues could be used for fast and standardised DNA extraction. The application of the three marker types was tested on a number of different Populus taxa, and they were also used for the verification of pure P. nigra in a sample of 304 putative $P$. nigra individuals from Switzerland. Cross-checking of the DNA data with those using a traditional allozyme approach resulted in complete agreement. The availability of molecular identification methods is an important prerequisite for the conservation of European Black Poplar, because pure, non-introgressed plant material can then be used in restoration projects of European floodplains.
\end{abstract}

Keywords Conservation - Molecular identification · Populus nigra Populus deltoides Populus x canadensis . Restoration

R. Holderegger $(\bowtie) \cdot S$. Angelone $\cdot$ S. Brodbeck

D. Csencsics · F. Gugerli · S. E. Hoebee

WSL Swiss Federal Research Institute,

Zürcherstrasse 111,

8903 Birmensdorf, Switzerland

e-mail: rolf.holderegger@wsl.ch

Tel.: +41-1-739-25-27

Fax: +41-1-739-22-15

R. Finkeldey

Institute of Forest Genetics and Forest Tree Breeding,

Georg-August University Göttingen,

Büsgenweg 2 ,

37077 Göttingen, Germany

\section{Introduction}

The European Black Poplar, Populus nigra L., is considered a rare and endangered tree species mainly because of two reasons: loss of natural habitats (Rotach 2001) and potential hybridisation along with genetic swamping by nonindigenous related taxa (Heinze and De Vries 1998; Heinze and Lefèvre 2001; Lefèvre et al. 2001; Heinze and Lickl 2002). Populus nigra is a typical species of riparian systems, where it dominates annually flooded forests along the banks of larger rivers and their tributaries. During the last two centuries, most European rivers have been braided and their hydroperiods drastically altered. This intensive river management did not only eradicate most natural habitats of $P$. nigra in European floodplains, but strongly disturbed the species' regeneration niche as well (Barsoum 2001). As a result of the strongly altered flooding dynamics of most European rivers, sexual regeneration of $P$. nigra in modern landscapes is low (Barsoum 2001). Habitat change and/or lack of sexual reproduction have caused a severe decline of $P$. nigra both in numbers of individuals as well as entire populations (Van Dam 2002).

Genetic swamping and introgression by related nonindigenous Populus taxa is supposed to threaten the species' genetic and evolutionary integrity (Vanden Broeck et al. 2002). In many European countries, American Black Poplar, P. deltoides Marsh., and Hybrid Poplar, P. x canadensis Moench (synonym $P$. x euramericana (Dode) Guinier; P. deltoides x P. nigra), have been widely planted for economic reasons (Heinze and Lefèvre 2001). Quite often, the remaining natural stands of $P$. nigra are small and close to such poplar plantations (Fossati et al. 2003). This is likely to increase gene exchange between $P$. nigra and the other two taxa either leading to first generation $\mathrm{F} 1$ or later-generation F2 and BC1 (backcross) hybrids. Thus, hybridisation and potential genetic swamping is seen as an additional threat to the in situ conservation of $P$. nigra. However, the amount of introgression of $P$. deltoides genes into the P. nigra gene pool is still debated (Benetka et al. 1999; Vanden Broeck et al. 2002). Recent reports from 
different European countries suggest that the probability of genetic swamping of native P. nigra is lower than previously thought (Vanden Broeck et al. 2004), and Heinze and Lickl (2002) state that this phenomenon is "rare but steady."

Floodplain restoration projects have now been started all over Europe (Lefèvre et al. 2002). In Switzerland, corresponding long-term and large-scale conservation measures have been or will be undertaken along the river Rhone in the central-alpine Valais and the rivers Aare or Thur in the Swiss Plateau (Dietiker and Jansen 2003; Rohde et al. 2004). These projects aim at restoring natural riparian woodlands including $P$. nigra forests. Hence, there is a demand for regional plant material of known taxonomic status, i.e. pure $P$. nigra seeds or plantlings. Unfortunately, it is not easy to identify pure $P$. nigra individuals from $P$. deltoides or $P$. x canadensis using morphological traits only (Van Slycken 1995; Kajba and Romanić 2002). It is thus difficult, first, to determine the actual abundance, state and distribution of pure P. nigra in Switzerland and, second, to identify naturally occurring $P$. nigra trees suitable as genetic resources for the above-mentioned restoration projects. Consequently, various molecular markers have been used to identify pure P. nigra individuals (Vornam et al. 1994; Janssen 1997; Heinze 1998, 2001; Rajora and Rahman 2003; Storme et al. 2004).

A practicable genetic marker approach should allow for different plant tissues to be used for DNA extraction (sampling in different seasons and from different life stages), use a molecular technique with high throughput and produce results that are easy to interpret (i.e. low number of different banding patterns). Because of the latter point, highly polymorphic markers such as nuclear microsatellites (Van der Schoot et al. 2000) or amplified fragment length polymorphisms, AFLPs (Arens et al. 1998; Winfield et al. 1998), do not seem to be the markers of choice for the purpose of species identification in P. nigra, although they are superior to less variable molecular markers in assessing local gene exchange or dispersal patterns (Rajora and Rahman 2001; Imbert and Lefèvre 2003; Tabbener and Cotrell 2003).

Here, we assess the applicability of a set of molecular markers for the discrimination of pure European Black Poplar from American Black Poplar and Hybrid Poplars in Switzerland using three PCR assays on both chloroplast DNA (cpDNA) and nuclear DNA (nDNA). We first show that different plant tissues can be used for fast and standardised DNA extraction, then describe the chosen markers' banding patterns and test their easy applicability on a set of different Populus taxa. Finally, we use this marker set for the identification of pure $P$. nigra in a large Swiss sample of morphologically determined, putative $P$. nigra individuals.

\section{Materials and methods}

\section{DNA extraction}

As a standardised, fast and high throughput DNA extraction procedure usable for different plant tissues of $P$. nigra, we modified the DNeasy 96 plant extraction kit (protocol for fresh plant leaves using a mixer mill; QIAGEN 2002). Fresh plant tissue samples $(50 \mathrm{mg})$ were first lyophilised for 3 days and then crushed in a shaker mill (RETSCH MM 300). DNA extraction followed the instructions of the supplier with the following modifications. Start by adding to the crushed plant material a mixture of $600 \mu$ l AP1 buffer, $1 \mu 1$ RNase and $1 \mu 1$ Reagent DX preheated to $65^{\circ} \mathrm{C}$, vigorously shake for $15 \mathrm{~s}$ and centrifuge at $5600 \mathrm{~g}$ for $15 \mathrm{~min}$; transfer $400 \mu 1$ of the supernatant to the collection tubes provided and add $130 \mu \mathrm{l}$ of AP2 buffer, vigorously shake for $15 \mathrm{~s}$, shortly spin down to collect all liquid, incubate for $15 \mathrm{~min}$ at $-20^{\circ} \mathrm{C}$ and centrifuge for $10 \mathrm{~min}$ at $56,000 \mathrm{~g}$; then proceed to step 8 according to QIAGEN (2002). DNA quality and quantity was checked against $\lambda$-standards on $1.5 \%$ agarose gels stained with ethidium bromide. Extractions were conducted using pealed winter buds, early and late summer leaves and wood cores. In the latter case, care was taken to include the active cambium region of the wood core.

\section{trnL-trnF/RsaI RFLP cpDNA marker}

The intergenic region trnL-trnF of cpDNA (Vornam et al. 1994; Demesure et al. 1995) was PCR-amplified and digested with $R s a$ I. The PCR reaction volume of $25 \mu \mathrm{l}$ contained approximately $10 \mathrm{ng}$ of genomic DNA, $2.5 \mathrm{U}$ Taq DNA polymerase (SIGMA), $1 \times$ PCR buffer, $1.7 \mathrm{mM}$ $\mathrm{MgCl}_{2}, 100 \mu \mathrm{M}$ of each dNTP, $0.2 \mu \mathrm{M}$ of forward and reverse primer (Demesure et al. 1995) and $\mathrm{ddH}_{2} \mathrm{O}$. Amplification was carried out on an MJ RESEARCH PTC-100 PCR machine with initial denaturing at $95^{\circ} \mathrm{C}$ for $3 \mathrm{~min}$, followed by 35 cycles of $94^{\circ} \mathrm{C}$ for $1 \mathrm{~min}, 56^{\circ} \mathrm{C}$ for $1 \mathrm{~min}$ and $72^{\circ} \mathrm{C}$ for 2 min with a final extension of $72^{\circ} \mathrm{C}$ for $10 \mathrm{~min}$. Restrictions of $10 \mu \mathrm{l}$ reaction volume were carried out overnight with $4 \mu \mathrm{l}$ of amplification product, $10 \mathrm{U}$ of $R s a \mathrm{I}$, $1 \times$ restriction buffer and $\mathrm{ddH}_{2} \mathrm{O}$ at $37^{\circ} \mathrm{C}$. Fragment banding patterns were detected on $2 \%$ agarose gels stained with ethidium bromide, and fragment sizes determined against a $100 \mathrm{bp}$ ladder (FERMENTAS). Interpretation of banding patterns followed Vornam et al. (1994).

\section{win3 nDNA marker}

The win3 primers and assay for distinguishing $P$. deltoides and P. nigra were first described by Bradshaw et al. (1994) 
and Heinze (1997). The win3 region of nDNA, activated during wound healing of plants, was PCR-amplified (for primer, see Heinze 1998) with an initial denaturing at $94^{\circ} \mathrm{C}$ for $3 \mathrm{~min}$, followed by 30 cycles of $94^{\circ} \mathrm{C}$ for $1 \mathrm{~min}, 50^{\circ} \mathrm{C}$ for $1 \mathrm{~min}$ and $72^{\circ} \mathrm{C}$ for $1 \mathrm{~min}$ with a final extension of $72^{\circ} \mathrm{C}$ for $4 \mathrm{~min}$. PCR mixture, electrophoresis and visualisation were carried out as presented above. Interpretation of banding patterns followed Heinze (1998).

\section{POPX/M $s$ I RFLP nDNA marker}

A peroxidase region, POPX, of nDNA was amplified (for primers, see Heinze 1998) and restricted with $M s p I$. PCR amplification used an initial denaturing at $94^{\circ} \mathrm{C}$ for $4 \mathrm{~min}$, followed by 30 cycles of $94^{\circ} \mathrm{C}$ for $45 \mathrm{~s}, 62^{\circ} \mathrm{C}$ for $45 \mathrm{~s}$ and $72^{\circ} \mathrm{C}$ for $2 \mathrm{~min}$ with a final extension of $72^{\circ} \mathrm{C}$ for $10 \mathrm{~min}$. PCR mixture, restriction mixture and procedure, electrophoresis and visualisation were carried out as presented above, interpretation of banding patterns followed Heinze (1997, 1998).

\section{Cross-checking with allozymes}

Allozymes have traditionally been used to identify pure P. nigra individuals from cultivated Populus taxa (Rajora 1989; Benetka et al. 1999; Storme et al. 2004). In order to cross-check the results obtained with the above three PCR methods, we conducted starch gel electrophoresis of four allozymes, namely, LAP-A (E.C. 3.4.11.1), AAT-B (E.C. 2.6.1.1), PGM-A (E.C. 5.4.2.2) and PGI-B (E.C. 5.3.1.9; Wendel and Weeden 1989) using 12\% starch gels. The methods used and subsequent interpretation of banding patterns followed Janssen (1997). We applied allozyme electrophoresis to a sub-sample of the Populus individuals studied (see below).

\section{Blind test samples}

To "blindly" check whether the combination of the above three PCR assays and the allozyme method enabled the secure identification of $P$. nigra and its delimitation from other Populus species or hybrids, an external person sampled winter buds from 79 trees representing diverse Рориlus taxa cultivated in Switzerland. These samples included, amongst others, known $P$. deltoides, $P$. nigra, $P$. nigra var. Italica (Cagelli and Lefèvre 1995) and $P$. x canadensis individuals. The identity of these samples was unknown to us. We subjected them to genetic analysis and subsequently compared our results with the known taxonomic status of the samples. The aim was to consistently delimit pure $P$. nigra from other Populus taxa.

\section{Putative P. nigra samples}

The three PCR assays were also applied to 304 naturally occurring adult individuals from Switzerland (Cantons of
Argovia, Berne, Thurgau and Zurich). Diverse tissues were sampled from these putative $P$. nigra trees identified as $P$. nigra by local foresters on the basis of their morphology during the vegetation period (EUFORGEN s.d.). Our assumption was that most of these individuals were pure $P$. nigra, but that confusion with $P$. deltoides and $P$. x canadensis could well have occurred. Therefore, we determined the corresponding mismatch rate between morphological and genetic identification of putative $P$. nigra. For 130 of these samples, for which bud tissue was available, we also conducted allozyme electrophoresis.

\section{Results}

\section{DNA extraction}

DNA extraction using the QIAGEN 96 plant extraction kit resulted in good quality DNA. Less than $5 \%$ of the samples did not properly amplify in PCR and needed additional cleaning (e.g. PROMEGA DNA clean up columns). In samples that supposedly contained high levels of polysaccharides, the addition of $200 \mu \mathrm{l}$ dichloromethane during the first step of the DNA extraction procedure increased the success rate of amplifications. DNA yield, however, was tissue dependent. Although extractions from buds and both early and late summer leaves typically gave yields of more than $50 \mathrm{ng} / \mu \mathrm{l}$, those from wood cores typically contained only about $5 \mathrm{ng} / \mu \mathrm{l}$, which was still sufficient to perform the three PCR assays below. Once collected, the plant material could be stored at room temperature for up to 2 weeks prior to lyophilisation without harming the quality of extracted DNA.

\section{trnL-trnF/RsaI RFLP of cpDNA}

Here (and below), we only refer to the banding patterns observed in $P$. deltoides, $P$. nigra and $P$. x canadensis. The restriction of the $\operatorname{trn} \mathrm{L}-\operatorname{trn} \mathrm{F}$ region of cpDNA with $R s a \mathrm{I}$ resulted in two distinct patterns (Vornam et al. 1994). The PCR product (1070 bp in length) of $P$. nigra was not cut (Fig. 1a, pattern A), while that of P. deltoides was digested into two bands of about 700 and 370 bp (site mutation; Fig. 1a, pattern B). Thus, the lack of an $R s a \mathrm{I}$ restriction site in the $t r n \mathrm{~L}-t r n \mathrm{~F}$ fragment of the pure P. nigra cpDNA robustly delimited this species from $P$. deltoides and from $P$. x canadensis stemming from a $P$. deltoides mother plant, since cpDNA is maternally inherited in poplars (Rajora and Dancik 1992).

\section{win3 nDNA}

PCR amplification of win3 nDNA resulted in four distinct banding patterns (Fig. 1b). Populus nigra either exhibited one band of about $170 \mathrm{bp}$ or two bands of 170 and $200 \mathrm{bp}$ (Heinze 1997, 1998; Fig. 1b, patterns cc and bc), while $P$. deltoides was characterised by one band of about $260 \mathrm{bp}$ 


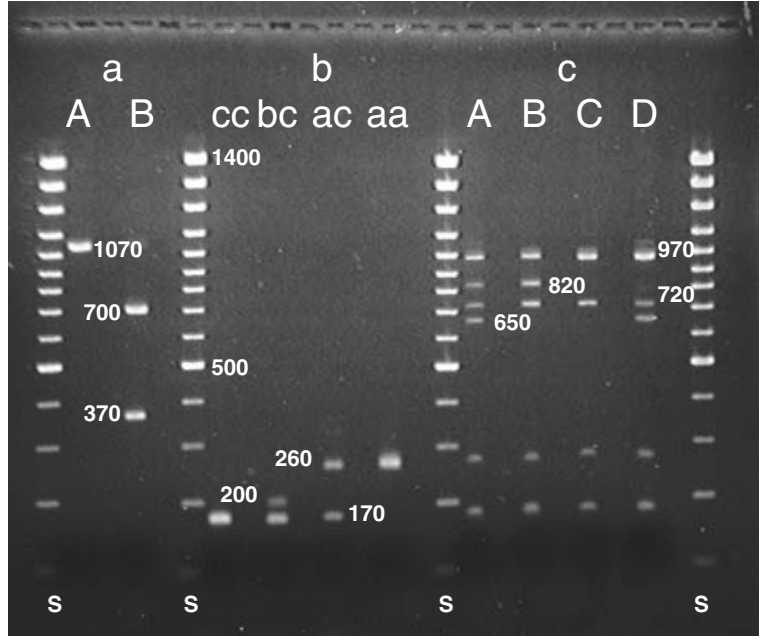

Fig. 1 Banding patterns observed in three PCR assays used for the identification of pure Populus nigra. a $\operatorname{trnL}-\operatorname{trn} \mathrm{F} /$ RsaI RFLP of cpDNA; pattern A: P. nigra (undigested); pattern B: P. deltoides and (typically) $P$. x canadensis. b win 3 nDNA; patterns cc and bc: $P$. nigra; pattern aa: $P$. deltoides; pattern ac: $P$. x canadensis. c POPX/MspI RFLP of nDNA; patterns B and C: P. nigra; patterns A and D: P. deltoides and $P$. x canadensis. Approximate band sizes are indicated, the standard (S) is a $100 \mathrm{bp}$ ladder (FERMENTAS)

(Fig. 1b, pattern aa). Populus $\mathrm{x}$ canadensis showed a combination of the $P$. deltoides and $P$. nigra patterns with two bands of 170 and $260 \mathrm{bp}$ in length (Fig. 1b, pattern ac). This band combination should be indicative of F1 hybrids. (Note that a $200 \mathrm{bp}$ band was not observed in these putative hybrids). Thus, the presence of a band at $260 \mathrm{bp}$ indicates that an individual is not a pure P. nigra.

\section{POPX/MspI RFLP of nDNA}

Restriction of the POPX PCR product of nDNA with $M s p$ I resulted in four patterns with two to four bands (Heinze 1998). Two bands of about $970 \mathrm{bp}$ (two close, almost comigrating fragments form a particularly strong band) and 720 bp occurred in all individuals checked (Fig. 1c). Populus nigra showed either none or only one additional band of $820 \mathrm{bp}$ (Fig. 1c, patterns B and C). On the other hand, $P$. deltoides and $P$. x canadensis had one additional band of 650 bp (Fig. 1c, pattern D) or two additional bands of 650 and $820 \mathrm{bp}$ (Fig. 1c, pattern A). Hence, the presence of a band at $650 \mathrm{bp}$ indicates that an individual is not a pure $P$. nigra.

\section{Cross-checking with allozymes}

The allozyme genotypes of the 209 Populus trees either from the blind test samples or the putative $P$. nigra samples (see below) were in full agreement with the results of the three PCR assays. We detected a sub-sample of the typical allozyme genotypes indicated by Janssen (1997) in Populus taxa from Switzerland. Of particular interest were those for Black Poplars and their hybrids. For P. nigra, the genotypes found were LAP-A n1n1, AAT-B n1n1, PGM-A $\mathrm{n} 1 \mathrm{n} 2$ and $\mathrm{n} 2 \mathrm{n} 2$ and PGI-B n2n2. For $P$. deltoides and/or $P$. $\mathrm{x}$ canadensis, LAP-A $\mathrm{d} 1 \mathrm{n} 1$ and $\mathrm{d} 1 \mathrm{~d} 1$, AAT-B $\mathrm{d} 1 \mathrm{n} 1$ and d1d1, PGM-A d1n2 and d1d1 and PGI-B d3n2 and d3d3 were observed (genotypes are given according to Janssen 1997; banding patterns not shown).

\section{Blind test samples}

The blind test resulted in almost complete consistency between the known and the genetically determined taxonomic identity. In particular, this held true for samples of $P$. deltoides, $P$. nigra and $P$. x canadensis. Two individuals supposed to represent pure $P$. nigra were determined as $P$. $\mathrm{x}$ canadensis based on the DNA and allozyme methods applied. All of the other Populus taxa within the blind test samples were easily delimited from Black Poplars and their hybrids. Populus nigra var. Italica showed the typical banding patterns of $P$. nigra.

\section{Putative $P$. nigra samples}

Only 8 out of the 304 putative $P$. nigra trees from Switzerland tested with the molecular marker set (and allozymes for about a third of them) were not pure $P$. nigra as indicated by the genetic methods applied. This resulted in a mismatch rate between morphological and genetic identification of pure P. nigra of only $2.6 \%$.

\section{Discussion}

We reliably distinguished $P$. nigra from $P$. deltoides and the hybrid $P$. x canadensis with the three PCR-based marker types used. These previously published markers proved to be easily applied in a large-scale screening, the PCR reactions were robust, and the results were straightforward to interpret (Fig. 1). A benefit was that diverse plant material both in terms of life stage (i.e. seedlings versus adults) and organ type (wood, leaves, buds) could be used for taxon delimitation. Hence, sampling of plant tissue of naturally occurring Populus trees is not restricted to a particular season, but can be done year round. This latter point and the distinct banding patterns observed are advantages of the used DNA markers over the traditional allozyme method, which requires buds (Rajora 1989; Janssen 1997). However, it should be noted that for the two nuclear markers win 3 and POPX, other banding patterns, additional to those presented in this study (Fig. 1), could be observed in F2 or $\mathrm{BC} 1 P$. $\mathrm{x}$ canadensis or in any later-generation hybrids and backcrosses.

The molecular approach that we used, targeting both cpDNA and nDNA, allowed for the identification of $P$. deltoides and, at least, of $\mathrm{F} 1$ hybrids of $P$. x canadensis. The two nuclear markers should be able to indicate potential $\mathrm{F} 2$ or $\mathrm{BC} 1$ hybrids with a probability of $75 \%$, but given the combination with a cpDNA marker, the probability to 
identify later-generation hybrids is even higher (see below). Populus $\mathrm{x}$ canadensis cultivars in Central Europe appear to be F1 hybrids (Heinze 1998). The relatively recent introduction of Hybrid Poplars is therefore not likely to have resulted in later-generation hybrid individuals so far.

It is well known from cultivar breeding and crossing experiments that $P$. nigra rarely acts as the dam in interspecific crosses of $P$. deltoides and $P$. nigra (Hofmann 2002). High-embryo abortion is induced when P. nigra acts as the mother. This seems to hold true for later-generation hybrids as well, although tests under natural conditions are scarce (Vanden Broeck et al. 2002). Vanden Broeck et al. (2003) suggested that the availability of conspecific pollen is the key factor limiting interspecific crosses under natural conditions. As a consequence, the probability that any hybrid $P$. x canadensis would exhibit the specific $P$. nigra cpDNA banding pattern A (Fig. 1a) is rather low, which strongly increases the power to detect even later-generation hybrids of $P$. nigra and $P$. deltoides. However, only the application of all three marker types used in this study allows the molecular identification of pure P. nigra with high certainty.

The sample set of putative $P$. nigra individuals from Switzerland indicates that specialists, such as local foresters with an adequate botanical training, are able to identify pure $P$. nigra with high accuracy based on a combination of morphological traits alone. It should be noted that our sample set only included putative $P$. nigra trees with rather typical morphological traits (EUFORGEN s.d.) and did not consist of a random sample of Populus sp. trees from Switzerland. Our collectors correctly identified pure P. nigra in $97.3 \%$ of these samples. This value is surprisingly close to the $3 \%$ of hybrids detected with allozymes in nine European gene bank collections, which could not be delimited from pure $P$. nigra based on their morphology alone (Storme et al. 2004). However, a direct comparison of individual morphology and genotype, based on the molecular markers presented here, using a large random sample of $P$. nigra, $P$. deltoides and $P$. $\mathrm{x}$ canadensis would be desirable to thoroughly test the congruity of morphological and genetic identification approaches of pure $P$. nigra.

Not surprisingly, the cultivar P. nigra var. Italica, forming a clone that originated from a single distinct individual, could not be delimited from natural P. nigra using the above DNA marker set. However, this variety is easily identified by its distinct fastigiate growth habit (Cagelli and Lefèvre 1995). Hence, this missing genetic resolution does not pose any practical problems at the adult stage. It also has to be stressed that the markers used do not allow for a test of autochthony of $P$. nigra individuals. For the latter purpose, more variable DNA markers like nuclear microsatellites (Rajora and Rahman 2001) or AFLPs (Winfield et al. 1998) have to be used and to be tested in extensive regional samples of Populus sp.

Because the three PCR assays used in this study provide an easy-to-use, robust molecular tool for the identification of pure $P$. nigra from $P$. deltoides and hybrid $P$. x canadensis, we advocate their use as a prerequisite for the conservation of European Black Poplar, both in situ and ex situ. Naturally occurring pure $P$. nigra trees can then serve as sources for plant material used in re-establishing riparian woodlands during ongoing restoration projects of floodplains throughout Europe.

Acknowledgements We thank Annie Diarra, Fabienne Bourquin and Amira Sepic for help in the laboratory, Peter Lawrenz for the sampling of the blind test poplars and many foresters and forest authorities, especially Markus Bolliger, for their support. We would also like to thank Patrick Bonfils, Andreas Rudow, Peter Rotach, Peter Schwab und Marcus Ulber for help throughout the work. This research was financed by the BUWAL/Swiss Federal Forest Direction. Finally, we thank Ivana Stehlik, Berthold Heinze and an anonymous referee for critical comments on the manuscript.

\section{References}

Arens P, Coops H, Jansen J, Vosman B (1998) Molecular genetic analysis of Black Poplar (Populus nigra L.) along Dutch rivers. Mol Ecol 7:11-18

Barsoum N (2001) Regeneration - requirements and promotion measures. In: Lefèvre $\mathrm{F}$, Barsoum $\mathrm{N}$, Heinze $\mathrm{B}$, Kajba D, Rotach P, De Vries SMG, Turok J (eds) In situ conservation of Populus nigra. IPGRI, Rome, pp 16-24

Benetka V, Mottl J, Vacková K, Pospíšková M, Dubsky M (1999) Estimation of the introgression level in Populus nigra L. populations by means of isozyme gene markers. Silvae Genet 48:218-223

Bradshaw HD Jr, Villar M, Watson BD, Otto KG, Stewart S, Stettler RF (1994) Molecular genetics of growth and development in Populus. 3. A genetic linkage map of Hybrid Poplar composed of RFLP, STS and RAPD markers. Theor Appl Genet 89:167-178

Cagelli L, Lefèvre F (1995) The conservation of Populus nigra and gene flow with cultivated poplars in Europe. Forest Genet $2: 135-144$

Demesure B, Sodzi N, Petit RJ (1995) A set of universal primers for amplification of polymorphic non-coding regions of mitochondrial and chloroplast DNA in plants. Mol Ecol 4:129_ 131

Dietiker F, Jansen E (2003) Das Sachprogramm Auenschutzpark Aargau - eine Zwischenbilanz mit Beispielen realisierter Waldprojekte im Freiamt. Schweiz Z Forstwes 7:274-280

EUFORGEN (s.d.) Populus nigra L. IPGRI, Rome

Fossati T, Grassi F, Sala F, Castiglione S (2003) Molecular analysis of natural populations of Populus nigra L. intermingled with cultivated hybrids. Mol Ecol 12:2033-2043

Heinze B (1997) A PCR marker for a Populus deltoides allele and its use in studying introgression with native European Populus nigra. Belg J Bot 129:123-130

Heinze B (1998) Molekulargenetische Unterscheidung und Identifizierung von Schwarzpappeln und Hybridpappelklonen. FBVA Ber 105:1-44

Heinze B (2001) PCR-RFLP analysis of introns of nuclear genes in Populus and Prunus. In: Müller-Starck G, Schubert R (eds) Genetic responses of forest systems to changing environmental conditions. Kluwer, Dordrecht, pp 117-127

Heinze B, De Vries SMG (1998) Integration nationaler und internationaler Generhaltungsprogramme: das EUFORGEN - Netzwerk Schwarzpappel in Österreich und den Niederlanden. In: Geburek T, Heinze B (eds) Erhaltung genetischer Ressourcen im Wald - Normen, Programme, Massnahmen. Ecomed, Landsberg, pp 178-188

Heinze B, Lefèvre F (2001) Genetic considerations for the restoration of riparian populations. In: Lefèvre F, Barsoum N, Heinze B, Kajba D, Rotach P, De Vries SMG, Turok J (eds) In situ conservation of Populus nigra. IPGRI, Rome, pp 25-35

Heinze B, Lickl E (2002) Rare, but steady, introgression in Austrian Black Poplar as a long-term risk? In: Van Dam BC, Bordács S (eds) Genetic diversity in river populations of European Black Poplar. Csiszár Nyomda, Budapest, pp 169-175 
Hofmann M (2002) Economic aspects of Black Poplar - hybrids, yield and utilisation of wood. In: Van Dam BC, Bordács S (eds) Genetic diversity in river populations of European Black Poplar. Csiszár Nyomda, Budapest, pp 205-212

Imbert E, Lefèvre F (2003) Dispersal and gene flow of Populus nigra (Salicaceae) along a dynamic river system. J Ecol 91:447-456

Janssen A (1997) Unterscheidung der beiden Schwarzpappelarten Populus nigra L. und P. deltoides Marsh. sowie ihrer Arthybride $P$. x euramericana (Dode) Guinier mit Hilfe von Isoenzymmustern. Holzzucht 51:17-23

Kajba D, Romanić B (2002) Morphological leaf variability of the European Black Poplar (Populus nigra L.) in natural populations in the Drava river basin in Croatia. In: Van Dam BC, Bordács S (eds) Genetic diversity in river populations of European Black Poplar. Csiszár Nyomda, Budapest, pp 221-227

Lefèvre F, Kajba D, Heinze B, Rotach P, De Vries SMG, Turok J (2001) Black Poplar: a model for gene resource conservation in forest ecosystems. Forest Chron 77:139-244

Lefèvre F, Bordács S, Cotrell J, Gebhardt K, Smulders MJM, Van den Broeck A, Vornam B, Van Dam BC (2002) Recommendations for riparian ecosystem management based on the general frame defined in EUFORGEN and results from EUROPOP. In: Van Dam BC, Bordács $\mathrm{S}$ (eds) Genetic diversity in river populations of European Black Poplar. Csiszár Nyomda, Budapest, pp $157-161$

QIAGEN (2002) DNeasy 96 plant handbook. QIAGEN, Valencia

Rajora OP (1989) Characterisation of 43 Populus nigra L. clones representing selections, cultivars and botanical varieties based on their multilocus allozyme genotypes. Euphytica 43:197-206

Rajora OP, Dancik BP (1992) Chloroplast DNA inheritance in Populus. Theor Appl Genet 84:280-285

Rajora OP, Rahman MH (2001) Microsatellite DNA markers and their usefulness in poplars and conservation of microsatellite DNA loci in Salicaceae. In: Müller-Starck G, Schubert R (eds) Genetic response of forest systems to changing environmental conditions. Kluwer, Dordrecht, pp 105-115

Rajora OP, Rahman MH (2003) Microsatellite DNA and RAPD fingerprinting identification and genetic relationships of Hybrid Poplar (Populus x canadensis) cultivars. Theor Appl Genet 106:470-477

Rohde S, Kienast F, Bürgi M (2004) Assessing the rstoration success of river widenings: a landscape approach. Environ Manage 34:574-589

Rotach P (2001) General considerations and basic strategies. In: Lefèvre F, Barsoum N, Heinze B, Kajba D, Rotach P, De Vries SMG, Turok J (eds) In situ conservation of Populus nigra. IPGRI, Rome, pp 8-15
Storme V, Van den Broeck A, Ivens B, Halfmaerten D, Van Slycken J, Castiglione S, Grassi F, Fossati T, Cottrell JE, Tabbener HE, Lefèvre F, Saintagne C, Fluch S, Krystufek V, Burg K., Bordásc S, Borovics A, Gebhardt K, Vornam B, Pohl A, Alba N, Agúdez D, Maestro C, Notivol E, Bovenschen J, Van Dam BC, Van der Schoot J, Vosman B, Boerjan W, Smulders MJM (2004) Ex-situ conservation of Black Poplar in Europe: genetic diversity in nine gene bank collections and their value for nature development. Theor Appl Genet 108:969-981

Tabbener HE, Cotrell JE (2003) The use of PCR based DNA markers to study the paternity of poplar seedlings. Forest Ecol Manage 179:363-376

Van Dam BC (2002) EUROPOP: genetic diversity in river populations of European Black Poplar for evaluation of biodiversity, conservation strategies, nature development and genetic improvement. In: Van Dam BC, Bordács S (eds) Genetic diversity in river populations of European Black Poplar. Csiszár Nyomda, Budapest, pp 15-32

Van den Broeck AH, Storme V, Cox K, Quataert P, Ivens B, Hostyn V, Halfmaerten D, Boerjan W, Van Slycken J (2002) Mating system of Populus nigra L. in a mixed poplar stand composed of $P$. nigra, $P$. deltoides and $P$. x euramericana. In: Van Dam $\mathrm{BC}$, Bordács $\mathrm{S}$ (eds) Genetic diversity in river populations of European Black Poplar. Csiszár Nyomda, Budapest, pp 6172

Van den Broeck A, Quataert P, Roldán-Ruiz I, Van Bockstaele E, Van Slycken J (2003) Pollen competition in Populus nigra females revealed by microsatellite markers. Forest Genet 10:219 227

Van der Schoot J, Pospíšková M, Vosman B, Smulders MJM (2000) Development and characterisation of microsatellite markers in Black Poplar (Populus nigra L.). Theor Appl Genet 101:317-322

Van Slycken J (1995) Plant descriptors for Populus nigra. In: Turok J, Lefèvre F, Cagelli L, De Vries S (eds) Populus nigra network second meeting. IPGRI, Rome, pp 13-24

Vornam B, Herzog S, Preisigmuller R, Hattemer HH (1994) Restriction-fragment-length-polymorphisms of a chloroplast photosystem-II gene from poplar and their use for species identification. Genome 37:747-750

Wendel JF, Weeden NF (1989) Visualisation and interpretation of plant isozymes. In: Soltis DE, Soltis PS (eds) Isozymes in plant biology. Dioscorides, Portland, pp 5-45

Winfield MO, Arnold GM, Cooper F, Le Ray M, White J, Karp A, Edwards KJ (1998) A study of genetic diversity in Populus nigra subsp. betulifolia in the Upper Severn area of the UK using AFLP markers. Mol Ecol 7:3-10 